\title{
Conflict management of riparian disputes ${ }^{\text {tr }}$
}

\author{
Paul R. Hensel ${ }^{\mathrm{a}, 1}$, Sara McLaughlin Mitchell ${ }^{\mathrm{b}, *}$, Thomas E. Sowers II ${ }^{\mathrm{c}, 2}$ \\ ${ }^{\text {a }}$ Department of Political Science, Florida State University, Tallahassee, FL 32306-2230, USA \\ b 341 Schaeffer Hall, Department of Political Science, University of Iowa, Iowa City, IA 52242, USA \\ ${ }^{\mathrm{c}}$ Lamar University, Department of Political Science, P.O. Box 10030, Beaumont, TX 10030, USA
}

\begin{abstract}
This paper builds on a large literature that explores the linkages between resource scarcity and interstate conflict. Focusing on competing claims over cross-border rivers, we analyze peaceful and militarized techniques used by states to manage river claims, and compare the success of these techniques for resolving the issues under contention. We focus on two key factors to account for variance in the use and effectiveness of conflict management strategies: water scarcity and institutions. We argue that high levels of water scarcity increase the frequency of explicit claims over fresh water, increase the chances of militarized conflict over these claims, and make it more difficult for conflict management institutions to be created or to be effective. We also examine the role of peace-promoting institutions, both river-specific and general institutions, arguing that institutional membership should promote peaceful attempts to resolve river claims. Analyzing data on river claims (1900-2001) from the Issue Correlates of War (ICOW) Project, we find that greater water scarcity increases the likelihood of both militarized conflict and peaceful third party settlement attempts, while river-specific institutions reduce militarized conflict and increase the effectiveness of peaceful settlement attempts.

(c) 2005 Elsevier Ltd. All rights reserved.
\end{abstract}

Keywords: River; Conflict; Scarcity; Regional; Management; Institutions

\footnotetext{
it A previous version of this paper was presented at the 2004 International Studies Association Meeting, Montreal, Quebec.

* Corresponding author. Tel.: +1 319335 2471; fax: +1 3193353400 .

E-mail addresses: phensel@garnet.acns.fsu.edu (P.R. Hensel), sara-mitchell@uiowa.edu (S. McLaughlin Mitchell), thomas.sowers@lamar.edu (T.E. Sowers).

${ }^{1}$ Tel.: +1 850644 7318; fax: +1 8506447324 .

${ }^{2}$ Tel: + 1409880 8539; fax: +1 4098801710 .
} 


\section{Introduction}

Many commentators have suggested that because of the importance of water and its increasing scarcity around the world, disagreements over shared water resources will be a leading source of conflict in the twenty-first century (e.g. Cooley, 1984; Homer-Dixon, 1991, 1994, 1999). ${ }^{3}$ Typical grounds for disagreement over a cross-border river, for example, include a downstream state's objection to pollution, excessive irrigation, or the construction of dams by an upstream state, which will decrease or degrade the quantity or quality of water available to the downstream state. Several notable disagreements over rivers have led to militarized conflict, such as numerous incidents between Israel, Syria, and Jordan in the 1950s and 1960s surrounding attempts by each side to divert water from the Jordan and Yarmuk Rivers, and more recent threats between Turkey, Syria, and Iraq over the construction of dams on the Euphrates River. Other disagreements have been managed more peacefully, such as Mexican-American disagreements over pollution in the Rio Grande and damming on the Colorado River. Recent empirical studies highlight the importance of shared water resources in international relations, finding a strong positive relationship between shared rivers and dyadic militarized conflict (e.g. Sowers, 2002; Toset, Gleditsch, \& Hegre, 2000).

Freshwater resources are distributed very unevenly around the world. Regions such as Europe and the Americas generally contain ample freshwater resources, while other regions such as the Middle East face increasingly severe water shortages. There are also significant differences in terms of the creation and success of institutions to manage cross-border rivers. For example, Europe has had longstanding regional organizations to oversee the Danube and Rhine Rivers, and North America has seen more than 50 years of bilateral U.S.-Canadian and U.S.Mexican institutions for the management of cross-border water resources, while there has been little success in managing rivers in the Middle East.

In this paper, we explore different types of settlement attempts employed by states to resolve river claims, and compare the success of these varying means for resolving contention between riparian states. We argue that regional differences in the frequency, intensity, and duration of interstate river conflicts stem from variance in two key theoretical factors: water scarcity and institutions (river-specific and general). We focus our empirical analyses on the Americas, Western Europe and the Middle East. This gives us a sample that includes the region with the greatest water scarcity and the least institutionalization (the Middle East), the region with the greatest degree of multilateral institutionalization of freshwater resources (Western Europe), and a region with the lowest level of water scarcity and primarily bilateral institutionalization (the Americas).

Our paper begins with the development of our theoretical argument, where we assert that water scarcity levels and international institutions influence the ways in which states try to

\footnotetext{
${ }^{3}$ The possibility of future water wars is part of a larger debate about the relationship between environmental resources and conflict, exemplified by the discussion between neomalthusians and cornucopians (e.g. Gleditsch, 2003). Neomalthusians predict that the earth's resources will not keep pace with the rapidly rising global population, and that conflicts over scarce resources are likely to become more prevalent in the future. Cornucopians, on the other hand, argue that resource scarcity can be overcome through technological innovation and social collaboration. Our results demonstrate that both positions have some validity. Consistent with neomalthusian arguments, we find that increasing levels of water scarcity increase the chances for militarized conflict over rivers, although such militarized incidents to date are rare. On the other hand, we find that river-specific and general institutions help states manage river conflicts peacefully, consistent with the cornucopian prediction that humans will find ingenious ways to resolve resource conflicts.
} 
resolve contentious claims over rivers and the effectiveness of those settlement attempts. In short, we argue states will be more likely to use militarized force to secure access to rivers and less likely to solicit third party assistance when water resources are scarce. We also contend that conflict management institutions will develop more often and be more effective in regions that are resource abundant. This is followed by a regional comparison of Western Europe, the Americas, and the Middle East with respect to freshwater scarcity and institutionalization from 1900 to 2001. The next section describes our spatial-temporal domain and research design. Finally, we present several empirical analyses testing our hypotheses on the management of river issues, and conclude with some thoughts on directions for future research.

\section{A theory of riparian conflict management}

The idea that resource scarcity enhances prospects for conflict is an old one in the study of international relations. One finds arguments linking resources to conflict in most major schools of thought in the field, including Realism, Liberalism, and Marxism. Realists contend that states are often compelled to acquire resources through force, especially if resources external to state boundaries are essential for maintaining a state's security and survival. Realists also emphasize the idea of relative gains and the security dilemma, that acquisition of resources by one state could be viewed by other states as threatening (or could lead to conflict directly if two or more states vie for the same resource). Liberals take a more optimistic view, asserting that markets can produce efficient trade for resources. States that are lacking important resources can simply trade for these goods in the international market. Finally, Marxists emphasize the importance of inequalities in economic systems. Resource scarcity can produce inequalities both globally and internally, which enhances the prospects for both interstate and intrastate conflicts. World systems theorists, for example, emphasize the conflict that arises between states in the economic core and those in the periphery (e.g. Wallerstein, 1974).

While all three schools of thought raise important arguments, we think they are missing an important part of the story. We believe that resource scarcity and institutionalization vary significantly across geographical regions of the world, which creates different local environments within which potential conflict arises. In other words, we should not observe the same patterns of conflict management across different geographical areas in the world, especially with respect to riparian conflicts, because there are significant regional differences in levels of freshwater scarcity. Resource poor areas create environments that are highly competitive, where the creation of institutions to manage conflict will be lacking and/or ineffective. Resource rich areas, on the other hand, will be faced with fewer potential conflict situations overall, which will enhance the prospects for the creation of institutions to manage conflicts that do arise. This suggests that the development and effectiveness of institutions to facilitate conflict management will be greater in resource abundant locations. We develop this argument more fully below, building on existing arguments in the literature on resource scarcity and conflict.

\section{Resource scarcity and conflict}

While states seek to acquire both renewable and nonrenewable resources, we focus on renewable resources, notably access to fresh water for personal, industrial, or agricultural uses. Water is a renewable resource in the sense that rainfall continually feeds ground water supplies. However, human consumption, irrigation, dams, and pollution of water sources, such as rivers, 
place serious demands on existing and future water supplies. ${ }^{4}$ The demand for water has increased exponentially as the world has experienced high levels of population growth and technological development. These increases in population and economic productivity are predicted to result in "continued degradation and depletion of rivers, aquifers, and other water resources" (Homer-Dixon, 1999: 14). Critchley and Terriff (1993: 332) make a similar argument: "Intensifying population growth, agricultural production, and economic development will place ever more pressure on current water supplies in the coming years, increasing the prospects for conflict and violence." Because the balance between the supply and demand for freshwater varies considerably across geographical areas, there is good reason to argue that these varying degrees of resource scarcity will produce very different environments within which conflict will emerge. ${ }^{5}$

Critchley and Terriff (1993: 332) point to both direct and indirect linkages between resource competition and conflict. They argue that resources directly result in conflict when (1) they are becoming increasingly scarce in a region, (2) they are essential for human survival, and (3) the resource can be physically seized or controlled. Freshwater supplies drawn from rivers clearly meet these conditions; they are becoming scarce in many regions (especially the Middle East and Northern Africa), they are obviously essential for human life, and it is possible to restrict the flow of rivers through the construction of dams or extensive irrigation projects (Sowers, 2002).

Critchley and Terriff assert that direct conflict over renewable resources will be rare, but competition over scarce resources will have a strong indirect effect on the propensity for conflict. ${ }^{6}$ Limited availability of resources places stress on society, which makes the society less stable and more conflict-prone. ${ }^{7}$ They, like Homer-Dixon (1991, 1994, 1999), believe that the probability of conflict rises due to "decreased agricultural production, economic decline, population displacement, and disruption of legitimate institutions and social relations. These societal effects of environmental change might often be interlinked, sometimes with reinforcing relationships." (Critchley \& Terriff, 1993: 333) These authors focus their attention on the

\footnotetext{
${ }^{4}$ According to the United Nations, one-third of the world population lives in countries that place moderate to high stress on their water supply, using more than $120 \%$ of a state's annual renewable water supply (World Meteorological Organization, 1997; cited in Sowers, 2002).

${ }^{5}$ Gleditsch (2001: 253) provides a nice summary figure summarizing these Malthusian type arguments. Population growth and high resource consumption per capita (demand-induced scarcity) lead to deteriorated environmental conditions (supply-induced scarcity), which increase resource scarcity further and create harsher resource competition; this process, when combined with inequality with respect to resource access (structural scarcity), increases the chances for violence.

${ }^{6}$ Stalley (2003) identifies another distinction in the literature on environmental scarcity and conflict, conflict arising when the state experiencing scarcity initiates it ("state-A-as-the-initiator" logic; Galtung, 1982), and conflict arising when scarcity in A creates problems (such as refugees) that flow across international boundaries. In our analyses below, we examine only those interstate militarized disputes that are directly related to a contentious claim over a cross-border river; in this regard we cannot make inferences about any indirect effects scarcity may have on intrastate or interstate conflict more generally.

${ }^{7}$ One implication of this indirect effect, discussed by Homer-Dixon (1999) and Gurr (1985), is that stable democratic regimes will be less likely to develop in countries that lack adequate natural resources, especially if they are also experiencing massive population growth and increased agricultural and/or industrial demands for such resources. Gurr (1985) and Midlarsky (1995, 2001), for example, contend that resource scarcity increases material inequalities, which leads to greater group conflict, which in turn decreases the viability of democratic regimes. Further, if democratic regimes have greater propensities to sign cooperative treaties and work through international institutions (e.g. Russett $\&$ Oneal, 2001), this suggests that resource scarcity, regime type, and institutional development are all inter-related. We do not explore these endogenous relationships carefully in this paper, but plan to return to this issue in future research.
} 
propensity for domestic or intrastate conflict to arise, and spend less time considering the effects of resource scarcity more broadly on interstate interactions.

Other scholars widen the scope further, examining the relationship between resource scarcity and interstate conflict. This can be traced back to early theorists, such as Choucri and North $(1975,1989)$, who contend that internal demands on resources push states toward outward expansion, increasing the possibility for conflicts to arise through hostile lateral pressure. Sprout and Sprout (1968) also argued that environmental conditions serve to constrain a state's behavior in the international sphere. More recently, a number of edited volumes, such as Environmental Conflict (Diehl \& Gleditsch, 2001) and Conflict and the Environment (Gleditsch, 1997a, 1997b), and special journal issues (Journal of Peace Research, 35(3)) have been dedicated to exploring the connection between conflict and the environment. While the empirical findings in this literature are varied, they show that the likelihood of militarized conflict is significantly increased by a number of environmental factors, including increased population growth (Choucri \& North, 1975; Stalley, 2003; Tir \& Diehl, 1998), contention over territory (Hensel, 2001; Huth, 1996; Vasquez, 1993), increased degradation of soil (Stalley, 2003) and land (Hauge \& Ellingsen, 1998), and low freshwater availability (Hauge \& Ellingsen, 1998).

In addition to these studies linking environmental resources broadly with conflict, scholars have begun to focus their attention on water resources in particular. The 1980s saw articles warning of impending water wars in the Middle East (e.g. Cooley, 1984). In more recent years, a variety of authors have conducted empirical analyses tying water resources to international conflict. Guner (1998) explores the role that the distributions of water resources play in terrorism and territorial disputes. Toset et al. (2000) focus directly on the impact of shared river resources on international conflict. Sowers (2002) analyses the relationship between shared rivers and militarized conflict, establishing the possibility that riparian conflicts vary significant among regions in the world. He also finds that the distribution of water resources is related to the intensity of international disputes between states that share water resources. In short, while the number of systematic empirical studies looking at shared water resources and the occurrence of militarized conflict is small, there does seem to be an emerging consensus that competition over cross-border rivers is dangerous.

While all of these studies tell us a great deal about the relationship between resource (or water) scarcity and the onset or escalation of conflict, they do not generally consider the effects of scarcity on peaceful conflict management practices. ${ }^{8}$ Peaceful settlements to resolve contentious issues are not necessarily the opposite of militarized conflict; in fact, it is very common to see both peaceful and militarized means employed by states to help resolve their differences. Furthermore, we believe that overall resource scarcity creates different environments for peaceful conflict management practices. If certain areas experience acute resource shortages, then they will experience direct conflict over such resources more often (and indirect conflict as well). In these environments, states will find it more difficult to negotiate bilateral or multilateral treaties to enhance cooperation along river basins.

Our approach is novel because we examine both militarized and peaceful strategies for managing river conflicts and assess these strategies' effectiveness. We focus on four key dependent variables: militarized conflict over the use or misuse of a river, two types of peaceful conflict management (bilateral negotiations and third party settlement activities), and the effectiveness

\footnotetext{
${ }^{8}$ A notable exception is Diehl and Gleditsch's (2001) edited volume, which devotes an entire portion of the book to studying peaceful conflict management of environmental conflict, as well as exploring the role of institutions and treaties on cooperation.
} 
of peaceful conflict management techniques in resolving (or terminating) competing claims to cross-border rivers. Unlike previous empirical research on rivers and conflict which typically examines all possible (or politically relevant) dyad-years, we focus on situations where two or more states explicitly make competing claims or demands over cross-border river resources. This allows us to clearly link the use of militarized force to explicit contention over a river resource, allows us to track both militarized and peaceful attempts to manage river claims, and produces variance in the types of conflict management strategies employed. Our theory focuses on two key explanatory variables: water scarcity and institutions. Conceptually, water scarcity reflects both the supply of freshwater resources and the demands on those resources. Institutions are defined as formal agreements that are designed to manage shared water resources (river-specific institutions) or more broadly as formal regional or global organizations that promote peaceful dispute settlement in their charters (general institutions).

\section{Water scarcity and conflict management}

As noted above, we feel that water scarcity levels create different environments for peaceful and militarized conflict management practices. With respect to militarized conflict management, our expectation is that areas suffering more acute water resource scarcity will experience militarized conflict over freshwater supplies more often. High scarcity levels should increase not only the opportunity for river conflicts (in terms of the number of competing claims to cross-border rivers), but they should also increase the willingness of states to resort to militarized conflict to pursue their water-related interests (Most \& Starr, 1989). When discussing the outbreak of simple scarcity conflicts, Homer-Dixon (1991: 107) explains how these conflicts emerge: "These renewable resources ${ }^{9}$ seem particularly likely to spark conflict because their scarcity is increasing rapidly in some regions, they are often essential for human survival, and they can be physically seized or controlled." These conflicts look much like those described by realists; gains from water usage/pollution by an upstream state result in losses for one or more downstream states, which produces zero-sum interactions. Such interactions enhance the probability of conflict, especially if the downstream country is highly dependent on upstream water supply, the upstream country has the ability to seriously alter the quantity or quality of water flowing downstream, there is a history of antagonism between upstream and downstream states, and the downstream state is more powerful militarily (Homer-Dixon, 1999: 139).

Turning to peaceful conflict management, we anticipate that high levels of water scarcity will depress the usage and effectiveness of management efforts. Highly salient competitions over scarce water resources may decrease the willingness of states to submit their claims to peaceful conflict management. However, competing states may have different preferences with respect to negotiating resolutions on their own (bilaterally) versus negotiating with the assistance of third parties. ${ }^{10}$ Bilateral peaceful negotiations may be viewed as more acceptable, given that parties retain greater control over the outcome. Previous work on territorial claims (Hensel, 2001) illustrates these differences among peaceful conflict management techniques, demonstrating that highly salient issues lead to bilateral negotiations more often than third party settlement. Similarly, we expect high levels of water scarcity to reduce the likelihood of third

\footnotetext{
${ }^{9} \mathrm{He}$ is referring to rivers and fish stocks.

10 Third party conflict managers include individuals, states, international organizations, and non-governmental organizations.
} 
party involvement, while bilateral negotiations should be more likely in regions with highly salient water issues.

While parties may agree to bilateral talks in regions with high water scarcity, they should find it more difficult to reach an agreement that will satisfy both the upstream and downstream states. Because upstream states are advantaged in their ability to control (and pollute) river water, this will make it difficult for agreements to be struck, unless the downstream state has some other bargaining leverage, such as a more powerful military. In areas like the Middle East where many countries' water demand exceeds their supply, the effectiveness of peaceful conflict management activities will be much lower. To sum up, we hypothesize that higher levels of water scarcity increase the chances for militarized disputes over a river and the frequency of peaceful settlement attempts, while decreasing the likelihood of agreements being reached. We also expect similar results for the demands placed on water. A challenger state that places high demands on its available water supplies should be more likely to employ militarized conflict than a state that makes few demands on water, and peaceful settlement attempts should be more likely in such a situation but less effective.

\section{Institutions and conflict management}

One of the key problems limiting cooperation between states in the international system is the lack of an overarching authority to enforce agreements. In the domestic sphere, the government can intervene to enforce contracts. Because of the lack of a central authority internationally, states are forced to find other mechanisms to enforce their agreements. One of the options available is for states to create institutions. Although these institutions do not enjoy the same amount of power as a government, they provide a structure for the enforcement of an agreement that should mitigate the need for militarized disputes to resolve conflict. Institutions offer a potential solution to the problem of managing common water resources. Institutions can serve to provide assurances that treaties will be followed by riparians (Sowers, 2002). A treaty without effective enforcement mechanisms is not likely to offset future conflict. ${ }^{11}$ Institutions can serve as an outlet for conflict management by providing an arena for riparians to resolve their differences, by providing neutral information, reducing uncertainty, and minimizing transaction costs (Keohane, 1984). Some institutions explicitly manage water-related conflicts, such as regional trade agreements in Africa (Powers, 2004a, 2004b). When an effective institution is present, a riparian dispute can be referred to the institution for resolution, which diminishes the possibility that the disputing parties will resort to the threat or use of force. Institutions may also have a more passive effect on conflict management (Mitchell \& Hensel, 2005), by creating regular forums that facilitate bilateral negotiations between members and encouraging norms of peaceful conflict resolution (Russett \& Oneal, 2001).

Institutions created by the United States and Canada to resolve their river conflicts provide great examples of the benefits of river-specific institutions for conflict management. The International Joint Commission (IJC) has existed since 1909 and regulates all shared water

\footnotetext{
${ }^{11}$ Whether institutions require strong enforcement mechanisms to effectively promote cooperation among member states is contested in the international relations literature. Some view strong enforcement as necessary because incentives to cheat always exist (e.g. Downs, Rocke, \& Barsoom, 1996), while others contend that compliance rates are high and that management rather than enforcement is essential for promoting cooperation (e.g. Chayes \& Chayes, 1993). We don't attempt to resolve this debate here.
} 
between the United States and Canada. Disputes between the riparians are referred to this international commission, which works to resolve contentious issues. The IJC has been effective in regulating the Great Lakes and overseeing numerous hydroelectric projects that involve both states. The United States and Canada also belong to a number of regional and global organizations that call for peaceful dispute settlement, such as the Organization of American States, the Rio Pact, and the United Nations. These shared institutional memberships create more general forums for peaceful negotiations over river issues. Thus we expect that institutions (river-specific or general) designed to manage riparian conflict will decrease the likelihood of militarized conflict, and increase the frequency and effectiveness of peaceful conflict management.

In this paper, we treat water scarcity and institutions as distinct independent variables; although they are clearly related. ${ }^{12}$ High levels of water scarcity probably make it more difficult for river-specific institutions to be created or for existing institutions to have strong effects on member states' behavior. River treaties are also more likely to be signed between democratic states and dyads that share multiple IGO memberships (Tir \& Ackerman, 2004). Future research will examine these relationships between water scarcity and institutions more carefully.

\section{Other factors influencing conflict management}

In addition to water scarcity and the presence of institutions, we expect that river management will be influenced by other factors that are less central to our theoretical argument. These include joint democracy, the dyadic power relationship between two potential disputants, the overall salience of the contested river, and recent interactions over the river.

Consistent with the democratic peace literature, joint democracy should lessen the likelihood of militarized conflict between riparians and increase the likelihood of the use and effectiveness of peaceful conflict management.

Since democracies rarely if ever fight one another and since they rarely experience civil war, there is no reason to believe that they will suddenly start fighting over resource issues... Moreover, if it is correct that democracies generally display more benign environmental behavior than do non-democracies, then democracies are also less likely to generate the kind of extreme environmental degradation which may be assumed to generate violent conflict. Thus, democracy may have a double effect in preventing armed conflict over the environment: it generates fewer serious problems and it provides other means of conflict resolution once these problems have arisen (Gleditsch, 1998: 389).

In other words, democratic states should be more willing to employ non-violent means of dispute resolution. This includes creating institutions, direct negotiations, and seeking the involvement of third parties to resolve the disputes. The International Joint Commission (U.S. and Canada) is an excellent example of how we expect democracies to resolve their differences. The United States and Canada created an institution that was not only effective in resolving their current dispute but also was effective in resolving future disputes and facilitating cooperation between the two riparians. In sum, we hypothesize that joint democracies are less likely to

\footnotetext{
${ }^{12}$ For a nice discussion of the relationship between resource scarcity and institutions, see Giordano, Giordano, and Wolf (2005).
} 
employ militarized means to pursue their river claims, but more likely to pursue agreements through peaceful negotiations. ${ }^{13}$

Homer-Dixon (1991) points out that the relative balance of military capabilities between upstream and downstream states in a river basin influences the potential for militarized conflict, especially if the downstream state is more powerful. We agree with this assertion, and argue further that greater power asymmetries in favor of the challenging state will diminish the chances for peaceful conflict management efforts (or agreements) and make the use of force more likely, especially if the river issue is highly salient. The more strongly both sides value a river for its water quality and quantity, the more difficult it will be to strike a peaceful bargain, especially if the upstream state pollutes or dams the river. Egypt is an excellent example of a powerful riparian that would appear more likely to resort to military force rather than negotiation if Sudan were to threaten their access to the Nile. Israel's military intervention to stop the diversion of the Jordan river is another excellent example.

We also try to capture the importance of the cross-border river to each contending party, what we call issue salience. Factors such as the population served by the river, the navigational or irrigational value of the river, and the presence of hydroelectric projects on the river will increase the value of the water supply to one or both sides. Previous research (e.g. Hensel, 2001) has demonstrated a strong relationship between issue salience and the occurrence of militarized conflict over territorial issues, as well as decreased effectiveness of peaceful conflict management efforts; we expect generally similar results for river issues.

Also drawing from Hensel (2001), we consider the impact of recent interactions over a given river issue. Two types of interactions appear likely to be especially important: recent militarized conflict over the issue, and recent failures in attempts to settle the issue peacefully. We believe that both types of interactions should increase future conflict and increase the frequency of peaceful attempts to settle issues, while reducing the effectiveness of these attempts.

Having laid out our theoretical expectations, which are summarized in Table 1, we turn now to a descriptive comparison of our three regions, followed by more rigorous empirical analysis to evaluate our theoretical hypotheses.

\section{Comparing regions}

The premise of our theoretical argument is that resource scarcity and institutionalization levels create different contexts for both peaceful and militarized conflict management, and that such differences should be evident when comparing different regions around the world. Several scholars have recently explored the importance of regional settings and the possibility of domain-specific laws (e.g. Lemke, 2002; Most \& Starr, 1989; Sowers, 2002). With respect to river conflicts, as noted above, Sowers (2002) finds a number of differences across regions of the world when analyzing a general model of resource scarcity and militarized conflict onset/ escalation.

\footnotetext{
${ }^{13}$ Regarding the effectiveness of democratic settlement attempts, though, there is reason to believe that democracies are less likely to be able to reach agreements in their negotiations - although more likely to carry out these agreements once they are reached. Democratic leaders generally face greater audience costs and other domestic pressures than do authoritarian leaders, with the implication that democratic leaders will find it harder to reach bargains that they believe they can implement without losing power or being overruled by other domestic political actors. If an agreement is reached between democracies, though, their commitments are likely to be more credible, and their agreements should thus be more likely to be carried out. See Hensel, Mitchell, and Sowers (2005) and Mitchell and Hensel (2005).
} 
Table 1

Hypothesized directional effects for independent variables

\begin{tabular}{|c|c|c|c|}
\hline \multirow[t]{2}{*}{ Independent variable } & \multicolumn{3}{|l|}{ Dependent variable } \\
\hline & Militarized conflict & Peaceful settlement attempt & End river claim \\
\hline Water scarcity & + & + & - \\
\hline Water demands & + & + & - \\
\hline River institutions & - & + & + \\
\hline General institutions & - & + & + \\
\hline Joint democracy & - & + & + \\
\hline Salience & + & - & - \\
\hline Capability asymmetry & + & - & - \\
\hline Recent militarized conflict & + & + & - \\
\hline Failed settlement attempts & + & + & - \\
\hline
\end{tabular}

Sowers (2002) examines the influence of shared rivers (interacted with contiguity), high water usage, and renewable water resources on the onset and escalation of dyadic militarized disputes from 1946 to 1992. Including all dyads in a single model for the entire world demonstrates that shared rivers and high water usage significantly increase the likelihood of conflict onset and escalation, while access to renewable water resources significantly decreases conflict onset and escalation. However, these findings vary across regions. Shared rivers have no effect on conflict escalation in the Americas, Europe, or the Middle East, but do increase escalation in African and Asian dyads. High water usage increases the probability of conflict initiation in most regions, although it has a negative effect in Asian dyads. Renewable water resources help to prevent conflict onset in the Americas and Asia, but have no statistically significant effect in Africa, Europe, or the Middle East. Sowers' study suggests that riparian conflicts vary significantly across geographical regions. Analyses of all pairs of states (or dyads) over time, while useful for uncovering general relationships, produce average effects across all regions and miss important localized effects.

We rely on two theoretical variables to account for geographical variance in the frequency, intensity, and management of riparian conflicts: water scarcity and institutionalization. We argued above that higher levels of water scarcity create competitive environments, within which competing claims to cross-border rivers will be more conflictual. Furthermore, river-specific or general conflict management institutions are less likely to form or be effective for resolving riparian disputes in water-scarce environments. To adequately capture global variance in water scarcity and institutionalization, we focus our empirical analysis on the Americas, Western Europe, and the Middle East, regions for which we have data on river claims. ${ }^{14}$

Although the needed data to measure water scarcity are not available anywhere in time series form, we have compiled the best available estimates of renewable water resources per capita, annual water usage per capita, and annual water usage as a percentage of renewable water resources. These estimates draw from a number of sources, including the UN FAO's AquaStat database, Peter Gleick's biannual The World's Water volumes, the World Bank's World Development Indicators volumes, the World Resource Institute's World Resources reports, and the UNESCO International Hydrological Program's water resources data. These sources offer

\footnotetext{
${ }^{14}$ We consider the Americas region to include all of North, Central, and South America and the Caribbean. Western Europe includes all territory from Iberia east to Germany and from the British Isles south to Italy. The Middle East includes all territory from Egypt east to Iran and from Turkey south to Yemen.
} 
estimates of our water variables for various countries across various years beginning in 1950, and we take the average score across these different values to produce an estimate of average water scarcity for each country. Our estimates are based on anywhere from two to more than forty values per country, and should be taken as a rough indicator of each country's average water scarcity over an extended period of time, rather than as an accurate measure of water scarcity at any single point in time.

Table 2A compares the Americas, Western Europe, and the Middle East with respect to three water-related measures: average renewable water resources $\left(\mathrm{m}^{3} /\right.$ capita), average annual water usage $\left(\mathrm{m}^{3} /\right.$ capita), and average annual water use (as a percentage of renewable resources). We see large differences across these regions when comparing average renewable water resources; the Americas have by far the largest level of renewable water $\left(51,906.9 \mathrm{~m}^{3} /\right.$ capita), much greater than renewable water levels in the Middle East $\left(1174.5 \mathrm{~m}^{3} / \mathrm{capita}\right)$. These mean differences across regions are statistically significant $(F=5.59,2$ d.f., $p<.01)$. Similar regional differences can be observed when comparing average annual water use as a percentage of

Table 2

Comparison of regions, 1900-2001

\begin{tabular}{|c|c|c|c|}
\hline \multicolumn{4}{|l|}{ A. Water scarcity } \\
\hline Region & $N$ & Average renewable water resources ( $\mathrm{m}^{3} /$ capita) & \\
\hline Americas & 25 & $51,906.9(75,175.0)$ & $F=5.59(2$ d.f., $p<.01)$ \\
\hline Western Europe & 15 & $11,682.8(24,476.8)$ & \\
\hline Middle East & 17 & $1174.5(2532.1)$ & \\
\hline Total & 57 & $26,369.9(55,732.8)$ & \\
\hline Region & $N$ & Average annual water usage ( $\mathrm{m}^{3} /$ capita) & \\
\hline Americas & 25 & $617.8(529.2)$ & $F=0.43(2$ d.f., $p<.66)$ \\
\hline Western Europe & 15 & $518.6(242.1)$ & \\
\hline Middle East & 17 & $682.2(500.7)$ & \\
\hline Total & 57 & $611.7(462.5)$ & \\
\hline Region & $N$ & Average annual water use (\% of renewable resources) & \\
\hline Americas & 25 & $6.1(7.7)$ & $F=5.27(2$ d.f., $p<.01)$ \\
\hline Western Europe & 15 & $22.8(19.9)$ & \\
\hline Middle East & 17 & $232.2(429.9)$ & \\
\hline Total & 57 & $77.9(251.5)$ & \\
\hline \multicolumn{4}{|c|}{ B. River institutionalization } \\
\hline Region & $N$ & Average treaties managing international rivers in region & \\
\hline Americas & 25 & $4.2(6.6)$ & $F=4.19(2$ d.f., $p<.03)$ \\
\hline Western Europe & 15 & $7.7(8.2)$ & \\
\hline Middle East & 17 & $1.4(1.8)$ & \\
\hline Total & 57 & $4.3(6.5)$ & \\
\hline \multicolumn{4}{|c|}{ C. General institutionalization } \\
\hline Region & $N$ & Average treaties of pacific dispute settlement (per state) & \\
\hline Americas & 25 & $5.9(2.1)$ & $F=34.58(2$ d.f., $p<.001)$ \\
\hline Western Europe & 15 & $3.3(1.0)$ & \\
\hline Middle East & 17 & $2.1(0.5)$ & \\
\hline Total & 57 & $4.1(2.2)$ & \\
\hline
\end{tabular}




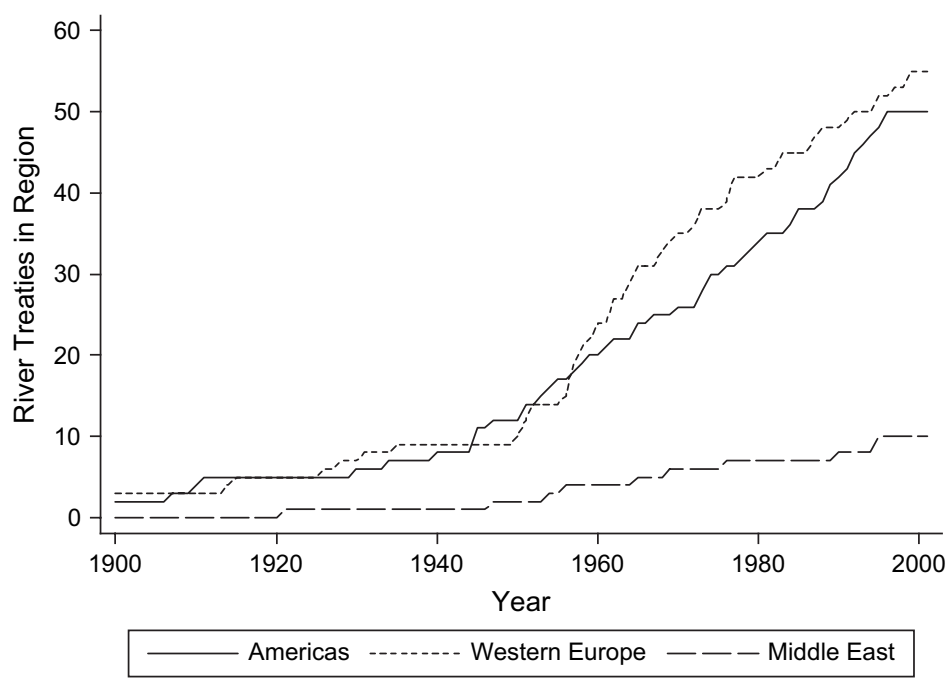

Fig. 1. Regional comparison of river treaties, 1900-2001.

renewable resources. States in the Middle East consume 232.2\% of their renewable resources in a typical year, damaging the long-term renewability of their water supplies, while Western Europeans and Americans consume fairly small percentages of their overall water resources ( $22.8 \%$ and $6.1 \%$, respectively). These mean differences across regions are again statistically significant $(F=5.27,2$ d.f., $p<.01)$. Average annual water usage per capita does not vary significantly across regions $(F=0.43,2$ d.f., $p<.66)$, although the mean for the Middle East is highest. In summary, the Middle East is clearly experiencing the greatest levels of water scarcity, while the Americas and Europe have significantly higher water supplies (and hence lower demand/usage as a proportion of the available supplies).

Our theory suggests that high water scarcity levels in the Middle East will inhibit the development and effectiveness of institutions to manage river conflicts in the region. Table $2 \mathrm{~B}$ and $\mathrm{C}$ and Figs. 1 and 2 compare average levels of institutionalization across the Americas, Western Europe, and the Middle East. As noted above, we consider two types of institutionalization: general and river-specific. River-specific institutionalization refers to the signing of treaties to promote cooperation among countries on a given river basin. This information is obtained from the Transboundary Freshwater Dispute Database (Hamner \& Wolf, 1998), which includes river treaties signed from 1820 to $2002 .^{15}$

Table 2B presents an analysis of variance for river institutionalization averaging across our entire time period (1900-2001). We can see that over the last two centuries, Western Europe has the highest level of river institutionalization, with the average state in the region being a signatory to 7.7 river treaties. As expected, high levels of water scarcity in the Middle East have

\footnotetext{
15 These treaties are described on the project's website (www.transboundarywaters.orst.edu): “The agreements collected relate to international freshwater resources, where the concern is water as a scarce or consumable resource, a quantity to be managed, or an ecosystem to be improved or maintained... The documents in the database concern: water rights, water allocations, water pollution, principles for equitably addressing water needs, hydropower/reservoir/flood control development, and environmental issues and the rights of riverine ecological systems." If a treaty was signed prior to the start of our data set (1900), we include it if it was still in effect during any years of our data (1900-2001).
} 


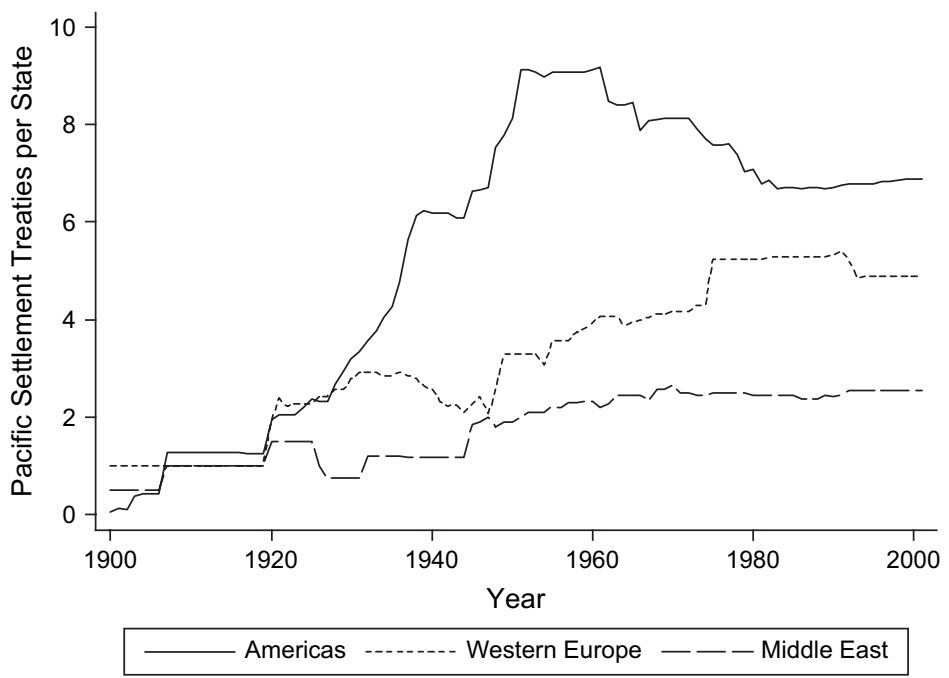

Fig. 2. Regional comparison of Pacific settlement treaties, 1900-2001.

depressed cooperative efforts to manage conflict over river basins; Middle Eastern states have signed only 1.4 river treaties on average (the Americas fall in the middle with 4.2 average river treaties per state). These differences in means are statistically significant $(F=4.19,2$ d.f., $p<.03){ }^{16}$

To consider temporal trends in river-specific institutionalization, Fig. 1 plots the number of river treaties in effect per year within each region. We can see that there were very few treaties in any region before World War II, and that the post-war period witnessed a trend of rapidly increasing numbers of river treaties. However, this growth occurred only in the Americas and Western Europe, with the number of river treaties increasing only slightly in the Middle East.

In addition to river-specific institutionalization, we also consider regional differences with respect to membership in peaceful conflict management institutions, which we refer to as general institutionalization. Even if these institutions do not specifically address the management of rivers, they call for their signatories to avoid the use of force and to pursue peaceful methods to resolve their disputed issues. To measure this general dimension of institutionalization, we utilize the Multilateral Treaties of Pacific Settlement (MTOPS) database, which has been collected by the Issue Correlates of War (ICOW) Project. ${ }^{17}$ The MTOPS data records the signature and ratification of all multilateral treaties and institutions at either the global or regional level

\footnotetext{
${ }^{16}$ A reviewer suggested that there may be an inverse- $U$ relationship between resource abundance and institutions, whereby fewer institutions would be created both in resource-scarce situations (as we argue) and in situations with great resource abundance (where there is little need to pay the costs of creating and maintaining institutions when there are sufficient resources to go around). The available evidence does not overwhelmingly support or refute this suggestion of an inverse- $U$ relationship, though, since we only have three regions to compare. Table $2 \mathrm{~B}$ reveals that the average state in the most resource abundant region (the Americas) participates in many more river institutions than in the most resource-scarce region (the Middle East), although fewer than in Western Europe (which has an intermediate level of scarcity falling between the other two regions).

${ }^{17}$ This data is available at $<$ http://www.icow.org $>$.
} 
that explicitly (in their charters/treaties) call for the pacific settlement of political disputes among members. ${ }^{18}$ Examples include general references to resolving disputes peacefully (e.g. UN Charter, Article 2), pledges to refrain from the use of force (e.g. Kellogg-Briand Pact, Article I), and procedures for resolving disputes with third party assistance, including good offices and mediation (e.g. 1907 Hague Treaty, Articles 2-8), arbitration (e.g. 1902 Treaty on Compulsory Arbitration), and adjudication (International Court of Justice, Optional Clause). ${ }^{19}$

Table 2C presents an ANOVA analysis comparing the average institutionalization within each region, measured as the average number of MTOPS treaties per state for each region, averaged across the entire time period. With respect to general institutionalization, the Americas scores highest, with an average of 5.9 institutions calling for peaceful conflict management; this indicates that in the average year from 1900 to 2001, the average Western Hemisphere state was constrained by nearly six treaties promoting pacific settlement. Once again, the Middle East exhibits the lowest regional average (2.2 institutions per state), while Western Europe falls in the middle. The difference in means across regions is statistically significant $(F=34.58,2$ d.f., $p<.001)$. Time series trends can be seen more clearly in Fig. 2, where we plot annual average MTOPS memberships per state in each region each year from 1900 to 2001. States in the Americas became members of numerous regional and global institutions committed to peaceful conflict resolution, especially after World War I. This regional average peaked around 1960 (over 8 institutional memberships per state in the region) and then declined a bit, although it still remains the highest average across all regions. ${ }^{20}$ The Middle East again shows the smallest average institutionalization; although the series shows a small upward trend over time, states in the region averaged membership only in about 2 global or regional institutions in 2001. It is also interesting to note the differences between Western Europe and the Americas. States in Western Europe have been very active in signing treaties to resolve differences over cross-border rivers specifically, whereas states in the Americas have relied more on general institutions that seek to encourage peaceful conflict management of all contentious issues. In general,

\footnotetext{
${ }^{18}$ This data set is limited to treaties with at least five signatories, and does not include economic organizations that also serve as conflict managers for political issues. For example, Powers (2004b: 16) analyses regional trade agreements (RTAs) in Africa, and finds that from 1950 to 2000, 44\% of African RTAs incorporated general water resource management agreements, while $22 \%$ included a water political boundary management agreement (e.g. where a river forms the border between two or more states). In the future, we plan to analyze the role that economic organizations play in managing river conflicts more carefully.

${ }^{19}$ Relevant global treaties include the charters of the League of Nations and United Nations, declarations accepting the compulsory jurisdiction of the Permanent Court of International Justice or International Court of Justice, the 1899 and 1907 Hague treaties on the peaceful settlement of disputes, and the Kellogg-Briand Pact. Relevant regional treaties in the Western Hemisphere include the charters of the Organization of American States and the Rio Pact (Inter-American Treaty of Reciprocal Assistance) as well as the 1902 Treaty on Compulsory Arbitration, 1923 Gondra Treaty, 1929 General Convention on Inter-American Conciliation and General Treaty of Inter-American Arbitration, 1933 Saavedra Lamas Pact, 1936 Treaty on Prevention of Controversies, 1936 Inter-American Treaty on Good Offices and Mediation, and 1948 American Treaty on Pacific Settlement (Pact of Bogotá). Western European treaties include the WEU's Brussels Treaty, the COE's Strasbourg Convention, the OSCE's Helsinki Final Act, and the NATO Charter. The only qualifying Middle Eastern treaty is the Pact of the League of Arab States.

${ }^{20}$ The decline in the Americas since 1960 is due primarily to the independence of numerous Caribbean states, most of which did not sign the various Latin American treaties promoting the peaceful settlement of disputes. Similarly, the apparent decline in MTOPS membership in Western Europe in the last few decades is due to several small states joining the COW system (Monaco, Liechtenstein, San Marino, and Malta).
} 
though, water scarcity does seem to create an environment where the creation of institutions is significantly less likely (we examine their effectiveness below).

These descriptive regional comparisons make it clear that water scarcity is quite different in the Americas, Western Europe, and the Middle East. We argued that these differences are a function of two theoretical factors: water scarcity levels and the presence or absence of river-specific or general institutions. In the next section, we focus on specific contention over rivers (what we call river claims), and then examine the frequency and effectiveness of peaceful versus militarized conflict management in these conflicts, capturing the effects of our two key variables in multivariate models. Below we describe an original data set, compiled as part of the ICOW Project, which will be used to evaluate our theoretical hypotheses.

\section{Research design}

Much of the existing literature empirically tests relationships between resource scarcity and interstate conflict using dyadic data, seeking to determine whether factors such as shared river boundaries or high water usage contribute to the probability of dyadic militarized conflict (Sowers, 2002; Toset et al., 2000). While these analyses have furthered our understanding about how environmental factors increase the chances for militarized conflict, they are limited in several ways. First, they often include all militarized disputes or wars occurring between pairs of states. This is problematic because militarized disputes arise for a variety of reasons; the Correlates of War Project, for example, categorizes the issues at stake in militarized disputes as involving territory, regime, policy, or other issues. If we find a correlation between water scarcity and dyadic conflict, we cannot be certain whether water scarcity caused conflict directly, or whether it simply had an indirect effect.

Second, there are many contentious issues that are resolved without the use of militarized force. If we code information only on those situations where the threat, display, or use of militarized force occurred, then we truncate the data such that peaceful interactions are missing. Bilateral negotiations that produced a treaty ending a contentious issue would be treated the same as situations where nothing happened (they would both be zeros in a dyadic data set), and we think this is limiting. The ICOW Project has attempted to overcome some of these limitations by collecting data on contentious issues, which produces variation on the militarized side; some contentious issue claims lead to one or more militarized disputes, while others do not. Focusing on explicit verbal contention over a specific issue makes it possible to compare peaceful and militarized conflict management practices more effectively.

The ICOW Project has collected data on three distinct contentious issues: territorial claims, maritime claims, and river claims. ${ }^{21}$ Given our theoretical focus in this paper, we include only river claim data in our present analysis. The river claims data are coded from 1900 to 2001, and currently include river claims in three regions: the Americas (North, Central, and South America and the Caribbean), the Middle East, and Western Europe. The data are organized around specific international rivers, rather than river basins. ${ }^{22}$ The project identifies explicit contention between official representatives over the use or abuse of such rivers. More specifically,

\footnotetext{
${ }^{21}$ For detailed information about the project, visit our website at $<$ http://www.icow.org $>$. Published papers using ICOW data include Hensel (2000, 2001) and Mitchell (2002).

${ }^{22}$ For greater discussion about the pros and cons of focusing on rivers versus river basins, see the ICOW River Claim Codebook (Hensel, 2005) available at $<$ http://www.icow.org $>$.
} 
Official representatives of the government of at least one state must make explicit demands over the quality or quantity of river water reaching their state through the territory of another state or over navigation rights on the river. Examples include demands to change policies - or to enact new policies - over the quantity of water flowing across the border (typically related to dams, irrigation, or other diversion projects), the quality of this water (typically related to pollution by industrial, agricultural, or human waste, or to excessive salination or sedimentation because of upstream activities), or the right to navigate along the river (typically for purposes of commerce or travel). (Hensel, 2005) ${ }^{23}$

A list of all qualifying river claims for the three regions is presented in Table 3 . There are a total of 28 dyadic river claims in the Americas, 47 in the Middle East, and seven in Western Europe. The frequency of dyadic claims is consistent with our expectation that the region with the greatest water scarcity would experience the greatest number of explicit disagreements over cross-border rivers. ${ }^{24}$

We utilize two distinct ICOW river claim data sets for our empirical analyses. The first, the claim dyad-year data, includes a separate dyadic observation for each year of an ongoing claim. For example, the Argentina-Uruguay claim over the Uruguay River (Río de La Plata) persisted from 1900 to 1973, and thus contributes 74 observations to the claim dyad-year data set. We have a total of 762 claim dyad-year cases across all three regions (361 in the Americas, 321 in the Middle East, and 80 in Western Europe). The second data set, the settlement attempt data, provides information on each peaceful attempt to resolve the claim. For example, there were five rounds of bilateral negotiations between Argentina and Uruguay in an effort to resolve the La Plata river claim. Peaceful settlement attempts can take the form of bilateral negotiations, good offices, inquiry/conciliation, mediation, arbitration, adjudication, multilateral negotiations, etc. There are a total of 190 peaceful settlement attempts for river claims in these three regions (96 in the Americas, 30 in Western Europe, and 64 in the Middle East).

\section{Dependent variables}

As noted earlier, we look at four distinct dependent variables to capture the use and effectiveness of peaceful and militarized conflict management. The first dependent variable codes militarized conflict over a given river claim. For each year of an ongoing dyadic river claim,

\footnotetext{
${ }^{23}$ These river claims are conceptually distinct from territorial claims, as studied by Hensel (2001), although some dyads engage in both at the same time. River claims involve water quantity, water quality, or navigation issues over the use of shared rivers rather than questions of territorial sovereignty. Less than one-fourth of the river claims in our data set involve rivers that flow through claimed territory, and less then $10 \%$ of dyads involved in territorial claims are also involved in river claims. For the relatively rare situations where the same adversaries are involved in simultaneous territorial and river claims, states' interactions over the river claim and territorial claim are considered separately based on whether a given round of negotiations or a given episode of militarized conflict involved territorial sovereignty or the use of a shared river.

${ }^{24}$ There is most likely a selection effect at work that we do not fully capture in this paper. For example, there might be fewer claims overall in Western Europe due to the strong political and economic ties between states in this region. To determine how these selection effects influence our empirical findings on conflict management, we would need to model claim onset. This would entail identifying a set of dyads that could experience river claims, such as starting with a list of all rivers of a particular length (e.g. 100 miles or more) that cross interstate boundaries, and then coding a first stage of river claim onset. Hensel et al. (2005) create a set of potential river claim cases for the Western Hemisphere, and find that only 14 of $162(8.6 \%)$ major rivers have been contested. We plan to apply these rules for potential river claim cases to other regions in future research.
} 
Table 3

ICOW river claims, 1816-2001

\begin{tabular}{|c|c|c|}
\hline Primary (secondary) river and claim description & Challenger-target & Dates \\
\hline \multicolumn{3}{|l|}{ North America } \\
\hline \multicolumn{3}{|l|}{ St. Lawrence River (Niagara) } \\
\hline Chicago Diversion & Canada-USA & $1925-1932$ \\
\hline \multicolumn{3}{|l|}{ Milk River (St. Mary’s) } \\
\hline St. Mary's Diversion & UK (Canada)-USA & $1902-1909$ \\
\hline Milk River Diversion & USA-UK (Canada) & 1904-1909 \\
\hline \multicolumn{3}{|l|}{ Red River (Souris) } \\
\hline \multirow[t]{2}{*}{ Garrison Diversion } & Canada-USA & $1973-1986$ \\
\hline & Canada-USA & $1999-$ \\
\hline \multicolumn{3}{|l|}{ Red River (Souris-Sheyenne) } \\
\hline Devil's Lake Diversion & Canada-USA & $1997-$ \\
\hline \multicolumn{3}{|l|}{ Souris River } \\
\hline Rafferty-Alameda Dam & Canada-USA & $1989-1992$ \\
\hline \multicolumn{3}{|l|}{ Columbia River (Kootenay-Frasier) } \\
\hline Libby Dam & Canada-USA & $1951-1961$ \\
\hline \multicolumn{3}{|l|}{ Skagit River } \\
\hline High Ross Dam & Canada-USA & $1972-1984$ \\
\hline \multicolumn{3}{|l|}{ Taku River } \\
\hline Tulsequah Chief Mine & USA-Canada & 1998- \\
\hline \multicolumn{3}{|l|}{ Colorado River } \\
\hline Alamo Canal & Mexico-USA & $1901-1904$ \\
\hline Colorado Apportionment & Mexico-USA & $1905-1944$ \\
\hline Wellton-Mohawk Salinity & Mexico-USA & $1961-1973$ \\
\hline All-American Canal Sealing & Mexico-USA & 1989-1999 \\
\hline \multicolumn{3}{|l|}{ Río Grande } \\
\hline Upper Rio Grande & Mexico-USA & $1900-1906$ \\
\hline Lower Rio Grande & USA-Mexico & 1924-1944 \\
\hline Mexican Water Release & USA-Mexico & $2000-$ \\
\hline
\end{tabular}

Central America and Caribbean

San Juan River San Juan Navigation

South America

Napo River

Petroecuador Oil Spill

Peru-Ecuador

1992-1992

Iguazú River

Segredo Reservoir

Paraná River

Itaipú Dam

Yacyreta Dam

Argentina-Brazil

1998-1998

Argentina-Brazil

1972-1979

Paraguay-Argentina

1973-1979

Paraguay River

Río Paraguay Navigation

Paraguay-Argentina

1941-1967

Pilcomayo River

Lower Pilcomayo Diversion

Uruguay River (La Plata)

Uruguay River Border

Mauri River

Mauri Irrigation Project

Paraguay-Argentina

1980-1983

Argentina-Uruguay

1900-1973

Bolivia-Chile

1921-1922

Lauca River

Lauca Diversion

Bolivia-Chile

1939-1978 
Table 3 (continued)

\begin{tabular}{llc}
\hline Primary (secondary) river and claim description & Challenger-target & Dates \\
\hline Silala River & & \\
$\quad$ Silala Fees (Ductec) & Chile-Bolivia & $1999-$ \\
Western Europe & & \\
$\begin{array}{l}\text { Meuse River } \\
\quad \text { Albert Canal }\end{array}$ & Netherlands-Belgium & $1930-1937$ \\
Rhine River & Switzerland-Germany & $1918-1918$ \\
$\quad$ German Hydroelectric Plan & Switzerland-France & $1919-1922$ \\
$\quad$ Grand Canal d'Alsace & Netherlands-France & $1979-1982$ \\
$\quad$ Alsace Salt Releases & Belgium-Netherlands & $1919-1932$ \\
Scheldt River & & \\
$\quad$ Scheldt/Wielingen Navigation & Spain-France & $1917-1967$ \\
Segre River (Ariege-Carol) & & \\
$\quad$ Lake Lanoux Diversion & Portugal-Spain & $1993-2000$ \\
Duero-Tejo-Guadiana Rivers & &
\end{tabular}

Middle East

Jordan River

Lake Huleh Diversion

Syria-Israel

1951-1951

DMZ Diversion

National Water Carrier

Jordan-Israel

$1951-1953$

Syria-Israel

1953-1954

Lebanon-Israel

1956-1966

Syria-Israel

1956-1958

UAR (Syria)-Israel

1959-1961

Syria-Israel

1961-1966

Jordan-Israel

1956-1966

Sewage Dumping

Jordan-Israel

1989-1989

West Bank Allocation

Jordan-Israel

1989-1989

Hasbani-Baniyas (Jordan)

Israel-Lebanon 1964-1966

Jordan Headwaters Diversion

Israel-Syria

1964-1966

Israel-Jordan

1964-1966

Hasbani River (Jordan)

Wazzani Pipe

Israel-Lebanon

2001-2001

Yarmuk River (Jordan)

Bunger Plan

Israel-Syria

1953-1956

Unity Dam

Israel-Jordan

1953-1956

Israel-Syria

1987-1998

Israel-Jordan

1987-1998

East Ghor Canal (Yarmuk/Jordan)

East Ghor Canal

Israel-Jordan

1969-1969

Jordan-Israel

1976-1994

Israel-Jordan

1999-1999

Yarmuk River

Yarmuk Diversions

Jordan-Syria

1987-1987

Jordan-Syria

1992-1998

Golan Heights Dam

Syria-Israel

1997-1998

Jordan-Israel

1997-1998

Mafraq Spill

Syria-Jordan

2000-2000

Euphrates River

Absolute Sovereignty

Syria-Turkey

1964-

Keban Dam

Syria-Turkey

1964-1966

Tabqa (Thawrah) Dam

Iraq-Syria

1975-1975 
Table 3 (continued)

\begin{tabular}{llr}
\hline Primary (secondary) river and claim description & Challenger-target & Dates \\
\hline Lake Assad & Syria-Turkey & $1983-1983$ \\
Ataturk Dam & Syria-Turkey & $1984-1990$ \\
& Iraq-Turkey & $1990-1990$ \\
Karakaya Dam & Syria-Turkey & $1986-1986$ \\
Iraqi Allocation & Iraq-Syria & $1988-1990$ \\
Birecik Dam & Iraq-Turkey & $1993-$ \\
& Syria-Turkey & $1995-$ \\
Tigris/Euphrates Rivers & & $1988-$ \\
Iraqi Allocation & Iraq-Turkey & $1999-$ \\
Tigris River & & $1921-1932$ \\
Ilisu Dam & Iraq-Turkey & $1932-1937$ \\
Shatt al-Arab & & $1953-1954$ \\
Thalweg \& Navigation & Iran-UK (Iraq) & $1958-1975$ \\
& Iran-Iraq & $1959-1975$ \\
& Iran-Iraq & $1979-1990$ \\
Syrian Dam Plan & Iraq-Iran & $1956-1958$ \\
& Iran-Iraq & $1958-1961$ \\
& Iraq-Iran & $1961-$ \\
\hline
\end{tabular}

we identify all militarized disputes where the claimants are on opposing sides, using version 3.02 of the Militarized Interstate Dispute data set (Ghosn \& Palmer, 2003). We then look through historical sources to determine whether the militarized dispute in question was related directly to the river claim in question; this allows us to capture more effectively whether the parties resorted to force because of contention over the quantity or quality of water in the river, and thus removes MIDs over other issues. ${ }^{25}$ We create a dummy variable in the claim dyad-year data set that equals one when a new militarized dispute related to the river claim was initiated in a given year, and zero otherwise. Militarized confrontations over river conflicts are quite rare; we observe a total of 12 dyadic MIDs related to river claims in the Middle East, five in the Americas, and none in Western Europe. Theoretically, we expect high levels of water scarcity to increase the likelihood of militarized conflict, while high levels of institutionalization (general and river-specific) will decrease the chances for militarized conflict.

The second and third dependent variables capture the peaceful side of conflict management efforts, including both bilateral and third party efforts. Again, we utilize the claim dyad-year data set. We create a dummy variable that equals one when one or more peaceful settlement attempts were initiated in a given year and zero otherwise. Bilateral settlement attempts are those that exclusively involved negotiations between the two claimants, while third party settlement attempts are those that involve a third party - whose activities can range from non-binding good offices, mediation, inquiry, or conciliation to legally binding arbitration or adjudication. We expect high

\footnotetext{
${ }^{25}$ To be considered relevant to a given river claim, the militarized dispute in question must have been - at least partly an explicit attempt to alter the status quo regarding the river in question. This coding is not intended to claim that the river claim provided the only or even the primary issue involved in the MID; any given militarized dispute may involve a number of different issues.
} 
levels of water scarcity to decrease the likelihood of peaceful settlements, while high levels of institutionalization will improve the chances for peaceful settlement.

Finally, we code a measure of the effectiveness of peaceful conflict management. Here the unit of analysis is the peaceful settlement attempt - whether bilateral negotiations, talks with non-binding third party assistance, or binding arbitration or adjudication - and we determine whether or not each such attempt was able to end the claim in question. ${ }^{26}$ A variety of measures could be used to indicate the effectiveness of a given settlement attempt, such as whether or not the attempt produced a treaty or agreement, or whether or not any such agreement was ratified and carried out by all of its signatories. Yet the most fundamental dimension of effectiveness is the question of whether or not a given attempt was able to end contention over the issue; this dimension is emphasized here. In general, we expect agreements to be more effective when institutionalization is high and water scarcity is low.

\section{Independent variables}

We have three key independent variables: water scarcity, river-specific institutions, and general conflict management institutions. Our measures for all three variables were introduced earlier when we compared these factors across regions, although our dyad-year and settlement attempt-level analyses code variables dyadically for a given year, rather than employing regional averages over an entire century. In the claim dyad-year data, one state is identified as the challenger (the state who first made a verbal claim about the quantity/quality of river water) and the other state is considered the target. Because the challenger is the one pressing its claim initially, we code water scarcity with respect to this state. In other words, water scarcity is operationalized as the challenger state's average annual water use as a percentage of its total renewable resources. Higher values on this measure indicate higher levels of water scarcity. We also supplement this measure of water scarcity with a measure of water demands, using Angus Maddison's data on historical GDP per capita. ${ }^{27}$ Although this is not a perfect measure, it does allow us to capture the general development level of an economy in a way that varies from year to year, is available for the entire period of study, and serves as a useful proxy for the overall water demands of the economy. ${ }^{28}$

Institutions were measured both with respect to river-specific treaties (Hamner \& Wolf, 1998), and broader commitment to peaceful conflict management (MTOPS). For each river claim dyad-year, we count the total number of river treaties between the challenger and target (and sometimes other states in the river basin), as well as the total number of global or regional institutions both states belong to that call for peaceful dispute settlement in their charters.

\footnotetext{
${ }^{26}$ For this analysis of effectiveness, we only consider settlement attempts that involved the attempted resolution of the underlying issue directly. This excludes "procedural attempts," where the parties attempt to set the stage for further talks, as well as "functional attempts" that seek to improve relations over the river in question in ways that do not address the specific substance of the original claim (e.g., by instituting confidence-building measures to allow joint usage of the river while a question about a dam project remains pending). By definition, neither procedural nor functional attempts can end a river claim, so they are inappropriate cases for our measure of effectiveness. Because these two types of settlement attempts do involve efforts to manage the river claim, though, they are included in our earlier analysis of the probability of peaceful conflict management efforts.

${ }^{27}$ Maddison's data is available at <http://www.eco.rug.nl/ Maddison/Historical_Statistics/horizontal-file.xls >.

${ }^{28}$ Future research could benefit from more direct measures of water demands, although such measures are generally available for much more limited temporal and/or spatial domains and will thus lead to the loss of many observations from analysis due to missing data.
} 


\section{Control variables}

Beyond water scarcity and institutions, we also consider a number of control variables that were introduced earlier. The first control variable, joint democracy, is a dummy variable indicating whether both the challenger and target state in a dyadic river claim score six or higher on the Polity IV democracy scale. ${ }^{29}$

River claim salience is coded by the ICOW Project and is based on six factors: (1) river location in the state's homeland territory rather than in colonial or dependent territory, (2) navigational value of the river, (3) level of population served by the river, (4) the presence of a fishing or other resource extraction industry on the river, (5) hydroelectric power generation along the river, and (6) irrigational value of the river. Each factor contributes one score per state to the overall salience index, producing a dyadic measure that ranges from zero (lowest salience) to twelve (highest salience). Previous research has shown that highly salient issue claims are more likely to produce militarized conflict and less likely to produce agreements through peaceful conflict management (e.g. Hensel, 2001).

Power asymmetry is coded based on the Correlates of War national material capabilities data set (Singer, Bremer, \& Stuckey, 1972). We calculate a CINC score for the challenger and target state in each river claim dyad-year; this represents the percentage of each state's military, economic, and demographic capabilities relative to all other states in the international system. Military capabilities are coded annually on the basis of the number of military personnel and total military expenditures; economic capabilities are based on iron and steel production and energy consumption, while demographic capabilities include total and urban population. We then create an asymmetry measure, dividing the challenger's CINC score by the sum of the challenger's CINC score and target's CINC score. This produces a variable ranging from zero (the target state has all of the dyad's capabilities) to one (the challenger state has all of the dyad's capabilities). Our expectations based on previous research suggest that increases in asymmetry favoring the challenger will make militarized conflict more likely, while decreasing the likelihood and effectiveness of peaceful settlement attempts.

Finally, we consider the history of recent militarized conflict over the river issue and failed recent attempts to settle the issue peacefully. We measure these recent interactions with respect to the five years before a given observation, and count the number of relevant events. Militarized conflict refers to recent militarized disputes, as discussed above; failed settlement attempts include any (bilateral or third party) peaceful settlement attempt that failed to reach an agreement, or that produced an agreement that was not ratified or carried out by at least one party (Hensel, 2001).

\section{Empirical analyses}

We developed theoretical expectations for four different dimensions of the management of river claims: the outbreak of militarized disputes over the claim, attempts to settle the claim

\footnotetext{
${ }^{29}$ States experiencing upheaval or transition in their polities (scores -66 through -99 on the Polity IV democracy scale) are coded as zero (not democratic), rather than coded as missing. It may be difficult to determine what kind of political system is operative in such cases, but it appears reasonable to conclude that, whatever it is, it is not a functioning political democracy.
} 
peacefully through either bilateral negotiations or third party activities, and the effectiveness of these peaceful settlement attempts. Table 4 presents logistic regression analyses for three of these dependent variables: militarized conflict (Model I), bilateral negotiations (Model II), and third party conflict management efforts (Model III). Because of the relative rarity of the events being studied, particularly militarized conflict, we also ran rare events logit models for each of these analyses; the results did not differ in any substantial way, and are not reported for reasons of space.

With respect to water resources, our theoretical expectations are weakly supported. Militarized conflict over the river (Model I) is more likely when the challenger state is experiencing greater water scarcity $(p<.04)$. Neither water scarcity nor water demands significantly influence peaceful attempts to manage river claims bilaterally (Model II), although greater scarcity for the challenger state increases the likelihood of third party conflict management efforts $(p<.01)$ and greater water demands by the challenger state decrease this likelihood somewhat $(p<.07)$.

The presence of institutions to manage competition over cross-border rivers is clearly important. Militarized conflict (Model I) is significantly less likely when the claimants are constrained by river-specific institutions $(p<.01)$. This is consistent with our argument that when an effective institution is present, a riparian dispute can be referred to the institution for resolution, which diminishes the chances for militarized disputes. With respect to peaceful conflict management of river claims (Models II and III), we find that general institutions increase both bilateral and third party settlement activities, while the effect of river-specific institutions is not significantly different from zero. Overall, this table supports our view that institutions provide forums for peaceful bargaining. General regional and global institutions are effective at bringing parties to the negotiating table, while institutions designed to manage

Table 4

Peaceful and militarized management of river claims

\begin{tabular}{llcc}
\hline Variable & Coefficient (robust S.E.) & & Model II: bilateral \\
\cline { 2 - 4 } & $\begin{array}{l}\text { Model I: militarized } \\
\text { conflict }\end{array}$ & $\begin{array}{l}\text { Model III: third party } \\
\text { conflict management }\end{array}$ \\
\hline Water resources & & & $0.02(0.01)^{* * *}$ \\
Challenger water scarcity & $0.02(0.01)^{* *}$ & $-.001(.01)$ & $-0.00(0.00)^{*}$ \\
Challenger water demands & $0.00(0.00)$ & $0.00(0.00)$ & $0.09(0.17)$ \\
Institutions & & & $0.14(0.10)^{*}$ \\
River institutions & $-1.29(0.45)^{* * *}$ & $-0.08(0.15)$ & $0.44(0.42)$ \\
General institutions & $0.32(0.15)^{* *}$ & $0.09(0.05)^{*}$ & $-0.11(0.08)^{*}$ \\
Controls & $-1.75(1.35)^{*}$ & & $-0.87(0.78)$ \\
Joint democracy & $0.21(0.15)^{*}$ & $0.65(0.31)^{* *}$ & $0.43(0.24)^{* *}$ \\
Claim salience & $1.28(0.98)^{*}$ & $-0.26(0.50)$ & $0.26(0.08)^{* * *}$ \\
Challenger capabilities & $0.33(0.37)$ & $0.13(0.22)$ & $-2.81(0.62)^{* * *}$ \\
Recent militarized conflict & $-0.16(0.20)$ & $0.35(0.08)^{* * *}$ & $N=735$ \\
Failed settlement attempts & $-6.22(1.21)^{* * *}$ & $-3.10(0.50)^{* * *}$ & LL: -180.68 \\
Constant & $N=735$ & $N=735$ & $X^{2}=56.39$ \\
& LL: -68.80 & LL: -278.30 & $(9$ d.f., $p<.001)$ \\
\hline
\end{tabular}

$* p<.10, * * p<.05, * * * p<01$ (one-tailed tests). 
shared river resources constrain member states' use of militarized force to pursue their goals. ${ }^{30}$ Our empirical findings lend support to institutionalist approaches, demonstrating that institutions can help to promote cooperation even when highly contentious issues are at stake. ${ }^{31}$

Most of the control variables in Table 4 (Models I and II) play significant roles in the expected directions. Model I shows that joint democracy decreases the likelihood of militarized conflict over rivers $(p<.10)$, while militarized conflict is more likely when the river claim is more salient to the claimants $(p<.09)$ and when the challenger has a greater capability advantage relative to the target state $(p<.10)$, although neither of the recent interaction variables (recent militarized conflict and failed settlement attempts) has a statistically significant impact. Models II and III reveal that joint democracy significantly increases the likelihood of bilateral negotiations over river claims $(p<.02)$, suggesting that democratic adversaries are more likely than others to pursue peaceful negotiations over their contentious issues. This is consistent with arguments in the democratic peace literature that democracies are more amenable to peaceful means for resolving conflicts (e.g. Dixon, 1994; Russett \& Oneal, 2001), although with respect to river issues this appears to be largely an effect on bilateral relations among the claimants themselves; there is no statistically significant impact on third party conflict management activities in this table. A history of recent failed settlement attempts significantly increases the likelihood of both bilateral and third party peaceful settlement attempts $(p<.001)$ and a history of recent militarized conflict significantly increases the likelihood of third party activities $(p<.04)$, suggesting that greater urgency based on past failures helps to generate additional attempts to settle the matter peacefully. Finally, salience of the river to the claimants also increases the probability of bilateral negotiations $(p<.05)$, indicating that states are more likely to try to settle matters that they consider more important. ${ }^{32}$

Table 5 follows Table 4's analysis of the occurrence of peaceful settlement attempts by examining the effectiveness of such attempts once they are employed. Our theory suggests that higher levels of water scarcity and demands on water resources should make it more difficult to end contentious river claims, while the presence of river-specific or general institutions will promote more effective conflict management. The empirical findings are mixed. With respect to water resources, scarcity levels have no systematic effect on peaceful termination of river claims, while higher water demands by the challenger state actually increase (rather than decrease) the probability of success $(p<.09)$. Our theoretical expectation linking institutions to success are partially supported; the prospects for success are strongly increased by shared river-specific institutions $(p<.01)$, while shared general conflict management institutions

\footnotetext{
${ }^{30}$ Surprisingly, though, we find that claimants that are constrained by more general conflict management institutions are significantly more likely to experience militarized conflict (Model I) over their river claims $(p<.02)$. We believe that this likely reflects a temporal effect, as the number of conflict management institutions has generally increased over time for most dyads, at the same time that the demand for fresh water has generally increased and the supply has generally decreased.

${ }^{31}$ Some "general" regional organizations include specific provisions for water management. Powers (2004b), for example, examines regional trade agreements that include water resource provisions. An interesting extension of our analyses in this paper would be to compare the effectiveness of river-specific treaties to international organizations (with and without water resource provisions in their charters).

${ }^{32}$ Salience actually has a negative impact on third party attempts $(p<.09)$, although this appears to be tied to the effect of recent militarized conflict (which Table 4 reveals to be associated with claim salience). It appears that salient claims that have produced recent armed conflict are most likely to attract third party involvement, while salient claims that have remained peaceful do not have the same ability to attract outside parties.
} 
Table 5

Peaceful termination of river claims

\begin{tabular}{lc}
\hline Variable & Coefficient (robust S.E.) \\
\hline Water resources & $-0.01(0.01)$ \\
Challenger water scarcity & $0.00(0.00)^{*}$ \\
Challenger water demands & \\
Institutions & $0.75(0.29)^{* * *}$ \\
River institutions & $-0.24(0.13)^{* *}$ \\
General institutions & \\
Controls & $-0.03(0.63)$ \\
Joint democracy & $-0.03(0.12)$ \\
Claim salience & $-1.09(0.71)^{*}$ \\
Challenger capabilities & $0.46(0.24)^{* *}$ \\
Recent militarized conflict & $-0.30(0.16)^{* *}$ \\
Failed settlement attempts & $-0.71(1.07)$ \\
Constant & $N=151$ \\
& LL: -67.04 \\
& $X^{2}=18.33$ \\
\hline
\end{tabular}

$* p<.10, * * p<.05, * * * p<01$ (one-tailed tests).

appear to decrease effectiveness $(p<.04)$. We think that the latter finding may partly be a temporal effect - these general institutions have proliferated at the same time that river claims have become more frequent and water scarcity has become more severe in many parts of the world and these institutions may simply be more effective at bringing adversaries to the table (as seen in Table 4) than at resolving their issues in any given round of negotiations. ${ }^{33}$ Joint democracy, claim salience, and challenger capabilities have little systematic impact, although greater challenger capabilities appear to decrease the effectiveness of settlement attempts somewhat $(p<.07)$. Recent conflict appears to increase the effectiveness of settlement attempts $(p<.03)$, suggesting that states are better able to end their claims when they have seen the risks of escalation firsthand. A history of failed settlement attempts, though, appears to weaken the prospects for successful resolution $(p<.03)$.

\section{Discussion}

Taken together, these tables suggest a fair amount of support for our theoretical expectations. Greater levels of water scarcity for the challenger state significantly increase the probability of both militarized conflict over the river claim and attempts to settle the claim with third party assistance, although with little systematic impact on the effectiveness of these peaceful attempts. River-specific institutions significantly reduce the risk of militarized conflict and increase the effectiveness of peaceful settlement attempts. General conflict management

\footnotetext{
${ }^{33}$ The type of institutional settlement may influence success rates. Claimants are more likely to comply with agreements that are reached with the binding assistance of institutions (arbitration or adjudication), but actually less likely to comply with agreements (relative to agreements reached through bilateral talks) reached with non-binding IO involvement (Mitchell \& Hensel, 2005).
} 
institutions are actually associated with an increase in the risk of militarized conflict over river claims and a decrease in the effectiveness of peaceful settlement attempts, although this may be due to a temporal effect, but these institutions do increase the probability of both bilateral and third party attempts to manage claims peacefully.

These results, particularly those for river-specific institutions, suggest that international institutions can help to overcome obstacles to cooperation in an anarchic international system. Even when the issue at stake is as important as water, a vital resource for human existence, we find that river institutions have been quite effective at reducing militarized conflict over the rivers in question and at promoting the success of negotiations over river-related issues. This is particularly consistent with the work of Mitchell and Hensel (2005), who suggest that institutions can have a "passive" effect of promoting conflict resolution among their members, even if they are not having an "active" effect by settling the conflict through direct involvement. $^{34}$

Several caveats to our analyses are in order, though. First, with respect to the militarization of river claims, it is clear that fewer river claims lead to militarized activity than is popularly believed. For all the academic and policy-oriented discussions of "water wars" dominating future conflict, we have identified only 17 militarized interstate disputes between 1900 and 2001 that explicitly involved attempts to alter the river-related status quo. One partial explanation for this lack of "water wars" - even in the Middle East, the region where most expect the worst conflict to occur - is that river-specific institutions have made a positive contribution to avoid armed conflict over rivers. Such institutions did significantly reduce militarized conflict in our analyses where they were present, although conflict was still rare even where no institutions existed at the time of the claim. Another partial explanation for the relative rarity of armed conflict over rivers may be that these river claims have not taken place in areas with the most extreme water shortages, and that future conflict might be more likely as water demands rise and water supplies decrease in both quality and quantity. Our analyses revealed that greater levels of challenger water scarcity increase the likelihood of armed conflict, so as scarcity levels are expected to rise in coming decades, we might reasonably expect militarized conflict to rise as well - although there is still room for hope if effective river institutions can be put into place to try to manage rivers peacefully.

On the other hand, despite the importance of challenger water scarcity as a predictor of militarized conflict over rivers, we must be careful not to overemphasize the role of water scarcity. For example, one reviewer suggested that high levels of water scarcity might be an almost necessary condition for disagreements over rivers to escalate to the point of militarized conflict, and that in the absence of scarcity, none of the other factors might plausibly matter as a source of conflict. Further analysis suggests, though, that this is not the case. Twelve of the seventeen militarized disputes in our data set broke out in river claims that involved navigational issues rather than issues of water quantity or quality, which would not be expected if scarcity was the

\footnotetext{
${ }^{34}$ Although we did not develop an explicit theoretical expectation about this, further research suggests that there is a more active effect of institutions as well as this passive effect. When the analysis presented in Table 5 is augmented with an additional variable distinguishing between bilateral and third party settlement attempts, as well as an additional variable indicating whether or not an international organization or institution was actively involved in the settlement attempt, both variables have positive and highly significant effects. That is, both bilateral attempts and activities directly involving international institutions are significantly more effective than are activities involving states as third parties. This is consistent with the work of Hensel et al. (2005) on the effectiveness of different types of settlement attempts, as well as the work of Mitchell and Hensel (2005) on the effectiveness of institutions.
} 
primary motivating factor behind militarization. ${ }^{35}$ Furthermore, 14 of these 17 militarized disputes featured a challenger state within one standard deviation of the mean level of water scarcity; in two cases the challenger was more than one standard deviation below the mean, and in only one was it more than one standard deviation above the mean. Comparing these three categories of low, average, and high challenger scarcity, the difference in militarized dispute propensity is not statistically significant $\left(X^{2}=2.52,2\right.$ d.f., $\left.p<.28\right)$, suggesting that most of the impact of scarcity on conflict comes from variation within the average category (i.e., when the challenger state's scarcity level is within one standard deviation of the overall population mean). While relatively high levels of water scarcity or high demands on water resources do appear to have an impact on conflict behavior, then, these factors are far from necessary conditions for conflict to occur.

Finally, it might be suggested that militarized conflict is most likely when a river claim overlaps with a territorial claim between the same adversaries. Less than one-fourth of the river claims in our study overlapped with territorial claims, but these cases are more prone to militarized conflict than river claims that occur in the absence of territorial contention. Adding a territorial claims variable to our analysis of militarized conflict produces a highly significant increase in the likelihood of conflict $(p<.001)$ - but this does not change the impact of our other key variables related to water scarcity, water demands, or institutions. Furthermore, the militarized disputes that occur in these cases are largely those that involve navigation rights along international rivers; there does not appear to be a systematic connection between territorial claims and militarized conflict over river water quality or quantity.

\section{Conclusion}

Social scientists have long been interested in understanding the relationship between environmental resource scarcity and violence. In this paper, we focus on a particular renewable resource, international rivers. While many scholars have demonstrated linkages between shared rivers, increased water scarcity, and the likelihood of both interstate and intrastate conflicts, very few efforts have been undertaken to study peaceful conflict management of contentious river claims. We assert that water scarcity levels create different contexts for both peaceful and militarized conflict management. Areas with high levels of water scarcity will experience more frequent conflicts over cross-border rivers, and the development and effectiveness of institutions to manage riparian conflicts will be lacking. We focus on four factors capturing the frequency and effectiveness of river conflict management: militarized disputes over cross-border river resources, bilateral or third party peaceful attempts to resolve river claims, and the ability to reach agreements that resolve riparian conflicts.

We contend that militarized disputes will be more likely in water scarce regions, especially if claimants place a high degree of value on the river (salience). On other hand, militarized disputes will be less likely if the contending states share membership in more general or river-specific institutions, if both are democratic, and if the target state has a large capability advantage over the challenger. Looking at peaceful conflict management, we assert that institutions, high levels of water scarcity, and joint democracy encourage peaceful conflict management efforts,

\footnotetext{
35 The militarized disputes in our study included one between Nicaragua and Costa Rica over navigation on the San Juan River, three between Argentina and Uruguay over navigation on the Río de la Plata, one between Bolivia and Chile over the Lauca River, two between Israel and Syria over Jordan River diversion projects, two between Turkey and Syria over the Euphrates River, and eight between Iran and Iraq over Shatt al-Arab navigation.
} 
while salience and capability advantages for the challenger discourage them. We also develop arguments about the effectiveness of peaceful conflict management, predicting that agreements will be struck more easily when the parties are members of general or river-specific institutions to manage conflict, and struck less often if the issue is highly salient, the parties are jointly democratic, or water scarcity levels are high.

We demonstrate first that there is considerable regional variation in water scarcity and institutionalization when comparing the Americas, Middle East, and Western Europe from 1900 to 2001. The Middle East faces the most serious water supply issues, and also has the lowest level of institutionalization. We argue that regional variance in the frequency, intensity, and management of cross-border river conflicts can be explained by two key factors: water scarcity levels and institutionalization (general and river-specific). We hypothesize that areas with high water scarcity and low institutionalization will experience more militarized conflict and less successful peaceful efforts to resolve river conflicts than places abundant in water resources and institutions. We test our hypotheses using data collected by the ICOW Project in the three regions. Our results are strongest for explaining variance in the onset of militarized disputes between river claimants, although our models of conflict management effectiveness also reveal important findings.

One obvious path for future research is to consider the endogenous relationships between many of our variables. We are treating institutions as exogenous in our empirical models, although there is reason to believe that high water scarcity levels depress the formation of both conflict management institutions and democratic regimes. Tir and Ackerman (2004), for example, treat the formation of river-specific institutions as their dependent variable and find that treaties are more likely to be signed between highly developed, democratic states who are economically interdependent and members of many international organizations. Many of these variables - institutions, democracy, and economic development - serve to reinforce each other, triangulating for peace (Russett \& Oneal, 2001). In the future, we will consider a multistage model that tries to account for these interrelationships.

A related issue has to do with the nature of our data. ICOW is collecting data on the basis of competing verbal claims over international rivers. In essence, our selection on this set may not be random with respect to some of our independent variables. Democracies may contend less over environmental issues because they manage their environments better (Gleditsch, 2001), and river claims may be most likely to arise when institutions are either non-existent or have failed. Future research should consider a two-stage model, where the first stage would consider all states that could potentially have disagreements over rivers (states located in the same river basin) and the second stage would examine the management of river claims once they begin. Such an approach could help to tease out the effects of institutions and regime type on the onset of contentious claims, as distinct from their effects on militarized and peaceful conflict management practices once claims have arisen. Given that many commentators warn of impending "water wars" in the future, understanding all of the interrelationships among these political, social, and economic variables and their influence on conflicts over scarce resources is an important task.

\section{Acknowledgement}

The National Science Foundation has provided generous support for Hensel and Mitchell's ICOW Project (SES-0214447 \& SES-0079421). We are grateful to Glenn Palmer for his useful comments and suggestions. 


\section{References}

Chayes, A., \& Chayes, A. H. (1993). On compliance. International Organization, 47, 175-205.

Choucri, N., \& North, R. C. (1975). Nations in conflict. San Francisco, CA: W.H. Freeman and Company.

Choucri, N., \& North, R. C. (1989). Lateral pressure in international relations: concept and theory. In M. I. Midlarsky (Ed.), Handbook of war studies. Ann Arbor, MI: University of Michigan Press.

Cooley, J. K. (1984). The war over water. Foreign Policy, 54, 3-26.

Critchley, W. H., \& Terriff, T. (1993). Environment and security. In R. Shultz, R. Godson, \& T. Greenwood (Eds.), Security studies for the 1990's. Washington, D.C.: Brassey's.

Diehl, P. F., \& Gleditsch, N. P. (2001). Environmental conflict. Boulder, CO: Westview Press.

Dixon, W. J. (1994). Democracy and the peaceful settlement of international conflict. American Political Science Review, 88, 14-32.

Downs, G. W., Rocke, D. M., \& Barsoom, P. N. (1996). Is the good news about compliance good news about cooperation? International Organization, 50, 379-406.

Galtung, J. (1982). Environment, development, and military activity: Towards alternative security doctrines. Oslo: Norwegian University Press.

Ghosn, F., \& Palmer, G. (2003). Codebook for the militarized interstate dispute data, version 3.0. Available from: $<$ http://cow2.la.psu.edu $>$.

Giordano, M. F., Giordano, M. A., \& Wolf, A. T. (2005). International resource conflict and mitigation. Journal of Peace Research, 42, 47-65.

Gleditsch, N. P. (1997a). Environmental conflict and the democratic peace. In N. P. Gleditsch (Ed.), Conflict and the environment. Dordrecht: Kluwer Academic Publisher.

Gleditsch, N. P. (1997b). Conflict and the environment. Dordrecht: Kluwer Academic Publisher.

Gleditsch, N. P. (1998). Armed conflict and the environment: a critique of the literature. Journal of Peace Research, 35 , $381-400$.

Gleditsch, N. P. (2001). Armed conflict and the environment. In P. F. Diehl, \& N. P. Gleditsch (Eds.), Environmental conflict. Boulder, CO: Westview.

Gleditsch, N. P. (2003). Environmental conflict: neomalthusians vs. cornucopians. In H. G. Brauch (Ed.), Security and the environment in the Mediterranean: Conceptualising security and environmental conflicts. Berlin: Springer.

Guner, S. (1998). Signaling in the Turkish-Syrian water conflict. Conflict Management and Peace Science, 16, $185-206$.

Gurr, T. R. (1985). On the political consequences of scarcity and economic decline. International Studies Quarterly, 29, $51-75$.

Hamner, J., \& Wolf, A. (1998). Patterns in international water resource treaties: the transboundary freshwater dispute database. Colorado Journal of International Environmental Law and Policy. 1997-98 Yearbook.

Hauge, W., \& Ellingsen, T. (1998). Beyond environmental scarcity: causal pathways to conflict. Journal of Peace Research, 35, 299-317.

Hensel, P. R. (2000). Territory: theory and evidence on geography and conflict. In J. A. Vasquez (Ed.), What do we know about war? Boulder, CO: Rowman and Littlefield.

Hensel, P. R. (2001). Contentious issues and world politics: territorial claims in the Americas, 1816-1996. International Studies Quarterly, 45, 81-109.

Hensel, P. R. (2005). Codebook for river claims data: issue correlates of war (ICOW) project. Available from: < http:// www.icow.org $>$.

Hensel, P. R., Mitchell, S. M., \& Sowers, T. E. (2005). Bones of contention: comparing territorial, maritime, and river issues in the Western Hemisphere. Working paper. Florida State University.

Homer-Dixon, T. F. (1991). On the threshold: environmental changes as causes of acute conflict. International Security, 16, 76-116.

Homer-Dixon, T. F. (1994). Environmental scarcities and violent conflict: evidence from cases. International Security, $19,5-40$.

Homer-Dixon, T. F. (1999). Environment, scarcity, and violence. Princeton, N.J.: Princeton University Press.

Huth, P. K. (1996). Standing your ground: Territorial disputes and international conflict. Ann Arbor, MI: University of Michigan Press.

Keohane, R. O. (1984). After hegemony: Cooperation and discord in the world political economy. Princeton, N.J.: Princeton University Press.

Lemke, D. (2002). Regions of war and peace. Cambridge: Cambridge University Press. 
Midlarsky, M. I. (1995). Environmental influences on democracy: aridity, warfare, and a reversal of the causal arrow. Journal of Conflict Resolution, 39, 224-262.

Midlarsky, M. I. (2001). Democracy and the environment. In P. F. Diehl, \& N. P. Gleditsch (Eds.), Environmental conflict. Boulder, CO: Westview.

Mitchell, S. M. (2002). A Kantian system? Democracy and third-party conflict management. American Journal of Political Science, 46, 749-759.

Mitchell, S. M., \& Hensel, P. R. (2005). Institutions and compliance with agreements. Working paper.

Most, B. A., \& Starr, H. (1989). Inquiry, logic, and international politics. Columbia, S.C.: University of South Carolina Press.

Powers, K. L. (2004a). Regional trade agreements as military alliances. International Interactions, 30, $373-395$.

Powers, K. L. (2004b). International institutions: Formal mechanisms for dealing with resource conflicts. Paper presented at the Journeys in World Politics workshop. University of Iowa, October 28-30th.

Russett, B. M., \& Oneal, J. R. (2001). Triangulating peace: Democracy, interdependence, and international organizations. W.W. Norton \& Company.

Singer, J. D., Bremer, S., \& Stuckey, J. (1972). Capability distribution, uncertainty, and major power war, 1820-1965. In B. M. Russett (Ed.), Peace, war, and numbers. Beverly Hills, CA: Sage.

Sowers, T. E. II. (2002). The politics of freshwater resources. Doctoral dissertation. Florida State University.

Sprout, H., \& Sprout, M. (1968). The dilemma of rising demands and insufficient resources. World Politics, 20, $660-693$.

Stalley, P. (2003). Environmental scarcity and international conflict. Conflict Management and Peace Science, 20, 33-58.

Tir, J., \& Diehl, P. F. (1998). Demographic pressure and interstate conflict: linking population growth and density to militarized disputes and wars. Journal of Peace Research, 35, 319-339.

Tir, J., \& Ackerman, Lt. Col. J. T. (2004). To share or not to share: politics of cooperation between riparian states. Paper presented at the Annual Meeting of the International Studies Association, Montreal, Quebec.

Toset, H. P. W., Gleditsch, N. P., \& Hegre, H. (2000). Shared rivers and interstate conflict. Political Geography, 19, 971-996.

Vasquez, J. A. (1993). The war puzzle. Cambridge: Cambridge University Press.

Wallerstein, I. M. (1974). The modern world-system. New York: Academic Press.

World Meteorological Organization (1997). Comprehensive assessment of the freshwater resources of the world. Stockholm: Stockholm Environment Institute. 